\title{
Localized Farmer's Information Dissemination System in Nigeria Using Mobile Networks
}

\author{
Ele, B. I. ${ }^{1}$, Odey J. A ${ }^{1}$, Frank, N. E. ${ }^{2}$ \\ ${ }^{I}$ Department of Computer Science, University of Calabar, Calabar, Nigeria \\ ${ }^{2}$ Department of Computer Science Akwa Ibom State College of Science and Technology, Ikono Akwa Ibom State - Nigeria
}

\begin{abstract}
Agricultural science performs a substantial function in monetary and societal growth in nearly all developing nations. Data on satisfactory excellence is an indispensable criterion for the development of all fields of farming. By means of the speedy growth of Information Technologies (ITs), data and information can be efficiently produced, warehoused, scrutinized, distributed, and utilized to reinforce agriculturalists and agricultural societies to enhance agricultural output and sustainability. Information facilities for agriculturalists at the nationwide and provincial levels are an auspicious novel field of investigation and presentation in the evolving field of e-agriculture. This paper aims to address the challenges associated with the dissemination of localized agricultural information to farmers within a localized region in Nigeria using mobile networks and explicitly examined the application of Information and Communication Technologies (ICTs) in disseminating agricultural information to farmers in Nigeria. Based on the findings of this study, it is recommended that the government should establish information centers with up-to-date information technology infrastructures and mini-community libraries in all rustic regions in Nigeria where modern agricultural information can be easily obtained by the farmers.
\end{abstract}

Keywords: Information, Agricultural Information, Localized Farmers, Mobile Networks, Information and Communication Technologies.

\section{INTRODUCTION}

Rural farmers in Nigeria are not well-known to yield sufficient food, possibly because of several limitations which include poor accessibility to well-timed and modern information that could help them accomplish optimum harvest from their farmlands. This information is extremely needed by the rustic agriculturalists and its availability is through extension personnel, communal libraries, state and local government agricultural agencies (ADP, TADP, etc.), email, or the World Wide Web (WWW) in a telecenter [21].

In this present-day information technology, telecenters offer the rustic agriculturalists with rapid and dependable information regarding enhanced saplings, improved approaches of farming and fertilizer utilization, pest, and weed management/annihilation, novel improvements in livestock production, and disease management, etc. However, rustic agriculturalists are still using traditional media such as rustic radio in accessing agricultural information. Other methods of delivering information to the rustic agriculturalists include print, audiovisual, TV set, movies, transparencies, pictures, drama, dance, folktale, group deliberations, get-togethers, displays, and presentations.

The application of information technology (mobile network) in agriculture is increasingly becoming steady in developing countries and this could facilitate self-reliance for national growth. Agricultural science performs a fundamental function in the social-economic progress of most African countries and is the key provider of financial development and durability [12,5]. Electronic agriculture describes an evolving arena concentrated on the improvement of agrarian and rustic expansion via enhanced information and communication procedures. The e-agriculture broadcasts valuable information via Decision Support System (DSS), Management Information System (MIS), and Expert System (ES) by permeating the User Interface and Knowledge Management System [4,5].

Rustic agriculturalists constituted the largest population of any developing nation such as Nigeria. Governments of developing nations have a key obligation of guaranteeing that there is sufficient rustic development in their numerous communities which would lead to operative and resourceful agrarian schemes that will not only supply food and animal protein but also nurture the use of natural resources in a maintainable way. As the rustic agriculturalists' dearth accessibility to information that would enable them accomplishes the highest agricultural harvest, they are not only groping in the dark but are motivated to the urban centers in search of good occupation, as the only choice for survival [13]. Saravanan [18] asserted that the slightest costly contribution for enhanced rustic agrarian improvement is sufficient 
accessibility to knowledge/information in areas of novel agrarian pieces of machinery, initial cautionary systems (drought, pests, diseases, etc.), better saplings, fertilizer, credit, marketplace costs, etc. Chauhan [7] opined that there have been inadequacies of customary pattern and library-based approaches of delivering such agrarian information to rustic agriculturalists that are usually uneducated and comparatively isolated from formal sources of information (e.g. extension stations, libraries). Aina [2] and Gakuru et al [9] were also of the view that agriculturalists would profit from international knowledge if information centers are created in all rural regions with complete modern information and communication gadgets.

Abdullah and Samah [1] described informatization as the conversion of an economy and society via the efficient utilization of Information and Communication Technologies in commercial, agriculture, communal, and public functions. The lack of access to basic agricultural knowledge and information by rural farmers in Nigeria which can due to some limitations has made the rural farmers stick to their ancient customary approaches of agricultural system and animal farming practice, thus, the resultant is deprived crop and livestock productivity [15]. Knowledge is power and the deficiency of accessing agrarian information hinders the agricultural development of any nation. Therefore, this study sought to examine the limitations of accessing agricultural information by rural farmers in Nigeria.

\section{Problem Definition}

Information is a vital constituent in agricultural development programs but agriculturists in Nigeria rarely feel the effect of agrarian modernization whichever as they lack access to such essential information or because it is inadequately circulated. The information delivered is solely concentrated on policymaker's investigators and those who manage strategy verdicts with inadequate consideration given to the information necessity of the bulkiest recipients of the policy verdict. The nonavailability of agrarian information is a pivotal attribute that has highly restricted agrarian development in developing countries especially Nigeria.

This study was therefore designed to identify the constraints which hinder rural farmers in Nigeria from accessing agricultural information for improved crop production and improved animal husbandry practices. The acquisition of such primitive skills by our rural farmers cannot aid the enhancement of agrarian harvest. These practices in our rustic agrarian system array from deprived farm harvest, the appearance of new crop and animal diseases, impermeable plant weeds and pests that attack farm crops, ancient farm tools, inadequate excellent fertilizers, etc. Over the ages, our rustic agriculturalists rely on aboriginal or native information for an enhanced agricultural system. Such information denotes the dexterity and knowledge acquired via verbal custom and rehearsal over several age groups (Nanda and Arunachalam, [14].
Agrarian information is at all times aimed to reach the rustic agriculturalists through extension personnel, communal libraries, radio, television, film displays, agrarian leaflets, state and local government agrarian organizations, etc. Rural agriculturalists in their exertion to access this agricultural information from obtainable bases, for healthier agricultural systems and enhanced farming yield, are challenged with several limitations, which this analysis seeks to address.

\section{REVIEW OF RELATED WORKS}

In a work published by Oyewole et al. (2013), the role and contributions of ICT in the development of agriculture around the Ibadan North West area council in Nigeria have been evaluated. The survey utilized well-structured questionnaires and 50 respondents were sampled, and frequency counts, percentages, and Pearson Product Moment Correlation were used for data analyses. The result shows that about $58 \%$ of the respondents have used ICT for about 1-5 years. The finding also indicated that there is a significant relationship between ICT and agricultural development. This assertion was supported by Buyukbay and Gunduz [6], their result shows that there was a solid association amid internet usage, computer usage, and social-economic features of the people. It was recommended that internet facilities should be made accessible to agricultural researchers to improve usage and contributions to agricultural development (Oyewole et al., 2013). The conclusion of Oyewole et al. (2013) that ICT has impacted agriculture has been supported by the finding of Patel and Patel (2013) in a study conducted to evaluate the use of cloud computing in the agricultural growth of rural India. It has been argued that cloud computing tools wedged optimistically the agricultural arena and associated facilities they deliver for consumers. This conclusion is in agreement with Buyukbay and [6], the authors established that for computer and internet technologies to be applied effectively in rural areas, extensive training for farmers and the establishment of ICT infrastructure are highly required. Buyukbay and Gunduz, [6] were able to figure out the significance of ICT application in agricultural development in rural areas of Tokat Province in Turkey. However, the major limitation of the study is that out of 184 questionnaires administered; only $30 \%$ were collected for the use of the internet and computer which were inadequate.

The study by Oyewole et al. (2013) established a clear relationship between ICT and agricultural development. However, it fails to indicate whether such a relationship is positive or otherwise. Furthermore, the representative sample used in the study was not adequate to reflect what is actually on the ground bearing in mind that a substantial number of the population in the study location are farmers. Moreover, it is not clear whether the samples are members of the farming community or academia in agriculture, or both. Therefore, the findings are not as dependable as they require clarifications. 


\section{APPLiCATION OF INFORMATION AND COMMUNICATION TECHNOLOGIES (ICTS) IN Agricultural DevelopMent}

\section{A. ICT Devices that Support Agricultural Development}

Singh et. al [19] reported that Agricultural Information System (AIS) is an automated system that comprises all the interconnected information which could help farmers in managing information and policy decision making. The ICT devices that help to facilitate farming activities encompassed presentations such as radio, television, cellular phones, computers, tablets and networking, hardware and software, satellite systems (Munyua and Adera [12]; Pande and Deshmukh, [16]). In the same way, Yimer [23]; Munyua, and Adera [12]) reported that radio is extensively used to notify consumers on agrarian subjects, comprising novel and improved agricultural methods, production management, and marketplace information. This shows that farmers may take advantage of using radio in the absence of technology, especially rural farmers. The Internet and web-based packages are extensively used in the distribution and dissemination of agrarian information, and marketing of goods and services. The study conducted by Ramli et al (2015) has shown evidence that ICT is an efficient resolution to glitches that militate against the development of the agricultural industries, like feeble marketing connections, inadequate information administration, near to the ground productivity, low income, and absence of multiplicity. Singh et al, [19] noted that the importance of ICT in agriculture by sharing agricultural information systems to farmers at all levels. But the major drawback of this research is that its references did not follow the format of the international standard.

\section{B. Potential Benefits of ICT in Agricultural Development}

Present researche that establish possible benefits of ICT in the advancement of agricultural technology have been well documented. This is likely because farmers are increasingly accepting new technological revolutions in the farming system and this paper presents several benefits of ICT in the agricultural industry:

(i) Enhancement of Operational Work Strength: The application of ICT could harmonize data amid providers and clients and likewise enhance the decisionmaking process. Moreover, it could facilitate the interchange of supply and demand information amid agriculturalists and industrialists (Kale et. al, [10]; Ramli et. al, 2015; Singh et. al, [19]).

(ii) Rise of Profit: Information and Communication Technology plays important role in enhancing the impact and performance of agricultural production and by extension directly alleviates poverty through credit and financial services (Bhalekar et. al., 2015).

(iii) Strategize Market Activity: The use of ICT enables entrepreneurs to access relevant and recent business information. This provides likelihoods for the younger generation, agro-based industrialists, to establish their network and websites irrespective of period and location (Bhalekar et. al., 2015; Pande and Deshmukh, [16]; Ramli et. al, [20]; Singh et al [19]). Yimer [23] indicates that ICT furnishes informed knowledge and information on agrarian pieces of machinery, superlative practices, marketplaces, price tendencies, and weather circumstances.

(iv) Opportunity for Information Exchange: Through the use of ICTs, industrialists can generate novel possibilities by all-pervading the international market and get contact with new partners, and exchange relevant information for their business sustainability. Moreover, industrialists can establish public-private firms globally that lead to viable self-reliance (Kale et al., [10]; Pande and Deshmukh, [16]; Ramli et al, [17]; Singh et al., [19]). Equally, Munyua and Adera [12] discovered that contemporary ICTs can enhance agrarian production by communicating knowledge and information to rustic agricultural communities.

(v) It Improves Economic Growth: ICT implements can be adopted in the agrarian sector to fast-track development and can lead to the progress of the national economy (Pande and Deshmukh, [16]. This implies that the application of ICT in agriculture can enhance national economic growth by facilitating farming activities within the required period. Likewise, the findings of Behera [4] et al. (2015) showed that E-agriculture adds worth to the lives of agriculturalists and end-users in maintainable development via e-governance, knowledge administration gateways, e-kiosks, and mutual service centers at the grassroot level.

(vi) Research in Agriculture: The significance of ICT in agricultural research is quite enormous. It supports policy and decision-making with the use of GIS such as disaster management and agro-environmental resource management. Patel and Patel (2013) developed a model that consisted of Cloud Agro System and e-Data Bank. It updates information on demand-supply, communication and communication devices, e-knowledge sharing, and research. The e-Databank is primarily to circulate information to farmers and comprises crop-related information, weather and soil information, growth progress monitoring, farmer's data, and experts' consultation. The benefits of the developed model include data management and readiness, reduced rural-urban drift, the motivation of both farmers and researchers to get involved in agriculture, improved security, reduced technical issues, and improvement of the overall economy.

\section{Challenges Associated with Application of ICT in Agricultural Growth}

In developing countries accessing adequate and functional internet services and other ICT facilities are among the major concerns to farmers both in the rural and urban areas. These challenges are discussed as follows: 
(i) Inadequate ICT Facilities and Personnel: Singh et al. [19] reported some existing issues to include inadequate accessibility of ICT services to rural farmers, lack of basic skills of using ICT facilities in agriculture, the inability of the government to deliver adequate ICT knowledge to farmers. Ramli et al. [17]) have proven that ICT is an efficient resolution to glitches that occur in the agricultural industries, like feeble marketing connections, inadequate information administration, low productivity, low income, and absence of multiplicity. Access to the internet and telecommunications are mostly limited to urban areas in many developing countries while rural areas remain beyond the ambit of new technology (Kale et al., [10]).

(ii) Infrastructure: Inadequate and unstable power supply, cost of hardware, and software are high concerning average rural dwellers Kale et al., [10, 21]. Similarly, Tarragona and Gelb (2005) maintain that awareness, time, cost of technology, system integration, and software availability are the main constraints of ICT adoption in horticulture. This argument corresponds with Wyche and Steinfield [22] who put forward that there is a misalliance amid the design of MIS and smallholder agriculturalists' acuities of their mobile phones' communication competencies.

(iii) Power Supply and Farmers' Perception of ICT Skills: In 2015, Barakabitze et al. [3] investigated the implementation of ICTs in Agricultural Research Institutes (ARIs) for the improvement of agricultural productivity in Tanzania. Outcomes revealed that the use of agricultural periodicals is restricted because of undependability and deprived connectivity of the internet, and regular power scratch.

(iv) Harmonization of Knowledge and Language: Kale et al. [10] explored the role of ICT in Agricultural Knowledge Management (AKM) by assessing prospects and challenges for the adoption of ICTs in India. The authors urge the harmonization of the basic and scientific research knowledge database and farmers' knowledge database adopted biologically and socially over some time. The research concludes that there is a need to develop an integrated policy framework to link the ICT-based initiatives for faster dissemination of agricultural information and knowledge among the various stakeholders in the sector. However, the research report that no ideal ICT developed that fits all situations (ibid). This claim was supported by Zewge and Dittrich [24] that ICT in agricultural science has extended considerably over the past few years with numerous contributions but still, there are long ways to go. Also, there are inadequate knowledge regions and methods, user interface design, and theories on how to develop an information system for rural community locations at present.

\section{RESEARCH METHODOLOGY}

The work is restricted to detailing groundbreaking farmer information facilities and concentrated on developments or services that deliver agrarian teaching and information to agriculturalists openly, via the usage of Information and Communication Technologies (ICTs), instead of detailing services that enable the interchange of information amid investigators and representatives. It concentrates on the usage of mobile technologies such as Radio: Dial-up (Agricultural Information on Request) and Consistent Radio Transmissions, E-Learning for Rudimentary Expertise, Farming Training and VideoBased Methods, Voice Information Distribution Services/Extension Services grounded on Mobile Phone

\section{A. Radio: Dial-up (Agricultural Information on Request) and Consistent Radio Broadcasts}

This comprises systematic radio transmissions delivering market costs or other agrarian information and dial-up radio that contain a sequence of squat section acoustic packages that offer agriculturalists with phone accessibility to pertinent information via a computerized voice scheme. This radio scheme is a communication core containing a frequently modernized, varied list of options of the pre-recorded agrarian subject.

\section{B. E-Learning for Rudimentary Expertise, Farming Training, and Video-Based Methods}

This class conceals the delivery of data and education material for agrarian services. The precise video-based method has numerous significant benefits to customary practices of agrarian content that are characteristically not in the native linguistic, and are envisioned for a welleducated spectator, utilize skilled vocabulary, inadequate proletarian horizontal pragmatisms, and persist unreachable in a sea of sprinkled media (Cunningham and Cunningham, $[8,20])$.

\section{Voice Information Delivery Services/Extension Services Based on Mobile Phone}

This comprises a telephone-grounded information distribution facility that delivers information on agricultural approaches and marketplace accessibility to enhance the lives of rustic agricultural communities. Solutions to these glitches can be obtained from the internet, but with connectivity, literateness, and linguistic blockades, and this is beyond the grasp of the enormous population of agriculturalists. The resolution involved an integrated messaging podium combining Interactive Voice Response (IVR) functionality, incorporated with a Customer Relationship Management application to aid incorporated call control and organization of an extremely bulky acoustic database (Cunningham and Cunningham, [8]). 


\section{RESUlTS AND DiscuSSIONS}

This study provides a detailed localized farmer's information dissemination system using a mobile network that is capable of educating farmers in local and remote areas in Nigeria on information regarding best agricultural practices, which will help to improve agricultural growth and development in the country. Farmers in local areas faced the challenges of accessing modern agricultural information and this hinders their productivity. Various agricultural services can now be easily delivered to rural farmers in Nigeria by using the localized farmer's information dissemination system proposed in this study.

Though some studies applied many different facilities and ICTs to supply agriculturalists information by employing mobile phone machinery at a rising degree to transmit agricultural information, and providing weather forecasts daily, universal data is produced somewhere else and given to the rural public through radio, television, and rural telecenters. The rural public is not included in the creation, authentication, assessment, comprehension, and gratitude of this information. Since it is a "take it or leave it approach", the rural public lingers as merely docile spectators.

The study also has a melded learning procedure by utilizing level transmission of knowledge, such as learning by performance, taking part in the investigation, assessment and knowledge organization, CD and intranetbased studying, head-on communications, etc., which play a vital function in capability development. This will enable farmers in rural areas to comprehend their basic information needs like market prices for their farm produce, weather forecasts, transportation services, storage amenities, crop diseases, cattle diseases, fertilizer requirements, and the need for direct interaction amid the extension workers and the farmers.

\section{CONCLUSION}

The paper has demonstrated that ICT facilitates agricultural growth for economic sustainability in many ways. This includes agricultural research, enhancement of market undertakings, interchange of pertinent information, profit-making, interacting agricultural sector globally, conducting research, and maneuvering economic growth for self-reliance and sustainability.

In this digital age, there is an urgent need for stress-free accessibility and operational use of agricultural information by rural farmers or agriculturists; hence, the need for the creation of information centers in all rustic societies in Nigeria. These centers will offer rustic agriculturalists the required agricultural information in a structure that would be understandable to them, considering the prevalent elevated illiteracy degree, ethnic variances, and restricted machinery.

It is imperative to know that local agriculturalists must not be doctored as mere users of general information. The agrarian subdivision necessitates a regimented learning public in the way of farmers' unions, cooperatives, ladies' groups, etc. The groundbreaking agriculturalist information dissemination system suggested in this study has a melded learning procedure by utilizing level transmission of knowledge, such as learning by performance, participatory investigation, assessment and knowledge organization, CD and intranet-based studying, head-on communications, etc., which play a vital function in capability development and translate the general information into location-specific information and thus enable the rustic agriculturists to embark on self-directed education.

Rustic agriculturalists in Nigeria are still retrograde concerning the modern improvements in numerous regions of agricultural practices, for instance, telecommunication infrastructures. Telecommunications infrastructure is the main feature of information distribution in rustic regions. Mehta [11] opined that telecommunications infrastructure links households, industries, institutions, infirmaries, libraries to each other, and a massive collection of automated information services.

This study, therefore, recommended that the government should provide communications infrastructure and well-equipped modern information centers in all the rustic regions in Nigeria to support the rustic agriculturalists' access to agrarian information for optimum farmhouse production. The government should also consider the necessity for rustic communities to have minicommunity libraries in their regions. By so doing, such communal libraries would be capable to employ a competent librarian to liaise with the staff of information centers in their area and help in apprehending pertinent agrarian information from the Internet, ministries of agriculture, and other agro-allied institutions. This apprehended information would then be repackaged in a form that the rustic agriculturalists would comprehend and put into practice for improved agricultural operations.

\section{REFERENCES}

[1] Abdullah, F.A., and Samah, B.A., (2013). Factors Impinging Farmers' Use of Agriculture Technology. Asian Social Science, 9(3), 120 .

[2] Aina, L.O. (2007). Globalization and Small-Scale Farming in Africa: What role for Information Centres? World libraries and information congress 73rd IFLA General Conference and council. Durban, South Africa.

[3] Barakabitze, A.A., Kitindi, E.J., Sanga, C., Shabani, A., Philipo, J., and Kibirige, G. (2015). New technologies for disseminating and communicating agriculture knowledge and information (AKI): Challenges for Agricultural Research Institutes (ARI) in Tanzania. The Electronic Journal of Information Systems in Developing Countries, 70.

[4] Behera, B.S., Das, T.K., Jishnu, K.J., Behera, R.A., Behera, A.C., and Jena, S. (2015). E-Governance Mediated Agriculture for Sustainable Life in India. Procedia Computer Science, 48, 623-629.

[5] Bhalekar, P., Ingle, S., and Pathak, K., (2015). The Study of some ICT Projects in Agriculture for Rural Development of India.

[6] Buyukbay, E. O., and Gunduz, O. (2013). An Investigation on Computer and Internet use for Agricultural Development in Rural 
Areas: A case study for Tokat Province in Turkey. African Journal of Biotechnology, 10(56), 11879-11886.

[7] Chauhan, N. M. (2010). Expectations of the Farmers from ICT in Agriculture. Indian Res. J. Ext. Edu. 10(1), 42-45.

[8] Cunningham, P., and Cunningham, M. (2009). Innovative Farmer Advisory Services Using ICT IST-Africa 2009 Conference Proceedings (Eds) IIMC International Information Management Corporation.

[9] Gakuru, M., Winters, K. and Stepman F. (2008) "An inventory of Innovative Farmer Advisory Services" Forum for Agricultural Research in Africa, www.faraafrica.org/media/uploads/File/NSF2/RAILS/Innovative_Farmer_ Advisory_Systems.pdf

[10] Kale, R. B., Rohilla, P. P., Meena, M. S., and Wadkar, S. K. (2015). Information and Communication Technologies for Agricultural Knowledge Management in India. Journal of Global International Journal of Computer Science and Mathematical Theory ISSN 25455699 Vol. 3 No.1 2017 www.iiardpub.org Communication, 8(1), 16-22.

[11] Mehta, P. (2003). Information Technology in Agriculture: Reaching the Unreached. In: National Workshop on ICT for Agriculture and Rural Development, Ahmadabad.

[12] Munyua, H. (2000). Application of information communication technologies in the agricultural sector in Africa: a gender perspective. In: Rathgeber, E, \& Adera, E.O. (Eds.) Gender and information Revolution in Africa IDRC/ECA. 85-123.

[13] Munyua, H., and Adera, E. (2009). Emerging ICTs and their potential in revitalizing small-scale agriculture. Agricultural information worldwide, 2(1), 3-9.

[14] Nanda, S., Arunachalam, S. (2010). Reaching the Unreached Community-based Village Knowledge Centres \& Village Resource Centres. Jamsetji Tata National Virtual Academy, M S Swaminathan Research Foundation, Chennai.

[15] Obidike, N. A. (2011). Rural Farmers' Problems Accessing Agricultural Information: A Case Study of Nsukka Local Government Area of Enugu State, Nigeria Nnamdi Azikiwe Library University of Nigeria, Nsukka.

[16] Pande, N., and Deshmukh, P. (2015). ICT: A Path towards Rural Empowerment through Telecommunication, E-governance, and EAgriculture. IBMRD's Journal of Management \& Research, 4(2), 47-54.

[17] Ramli, S.A., Samah, B.A., Hassan, M.S., Omar, S.Z., Bolong, J. and Shaffri, H.A.M. (2015). Potential Benefits of ICT for Youth Agro-based Entrepreneurs in Malaysia. Journal of Applied Sciences, 15(3), 411.

[18] Saravanan, R. (2013). E-Agriculture Prototype for Knowledge Facilitation among Tribal Farmers of North-East India: Innovations, Impact, and Lessons. The Journal of Agricultural Education and Extension 19(2), 113-131.

[19] Singh, K. M., Kumar, A., \& Singh, R. K. P. (2015a). Role of Information and Communication Technologies in Indian Agriculture: An Overview. Available at SSRN 2570710.

[20] Singh, V., Sankhwar, S., and Pandey, D. (2015b). The Role of Information Communication Technology (ICT) in Agriculture. Global Journal of Multidisciplinary Studies, 3(4).

[21] Taragola, N., and Gelb, E. (2005). Information and Communication Technology (ICT) adoption in horticulture: A comparison to the EFITA baseline. ICT in agriculture: Perspectives of technological innovation. Telecoms Development Group (2000). Rural access to information and communication technologies (ICTs): The challenge for Africa (Draft). African Connection Secretariat.

[22] Wyche, S., and Steinfield, C. (2015). Why Don't Farmers Use Cell Phones to Access Market Prices? Technology Affordances and Barriers to Market Information Services Adoption in Rural Kenya. Information Technology for Development, 1-14.
[23] Yimer, M. (2015). The Role of ICT for Good Governance and Agricultural Development in Ethiopia: Local Evidence from Southern Ethiopia. International Journal of Political Science and Development, 3(1), 30-39.

[24] Zewge, A., and Dittrich, Y. (2015). Systematic mapping study of information communication technology research for agriculture (in the case of developing countries). 